Supplement of Biogeosciences, 14, 203-214, 2017

http://www.biogeosciences.net/14/203/2017/

doi:10.5194/bg-14-203-2017-supplement

(C) Author(s) 2017. CC Attribution 3.0 License.

(c) (i)

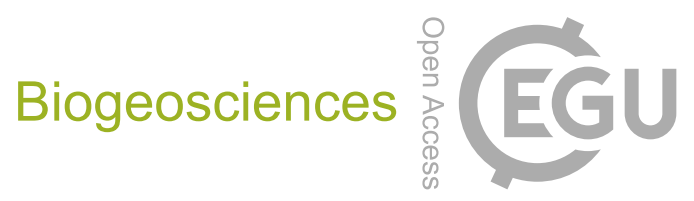

Supplement of

\title{
Seasonal distribution of short-tailed shearwaters and their prey in the Bering and Chukchi seas
}

\section{Bungo Nishizawa et al.}

Correspondence to: B. Nishizawa (nishizawa@ salmon.fish.hokudai.ac.jp)

The copyright of individual parts of the supplement might differ from the CC-BY 3.0 licence. 

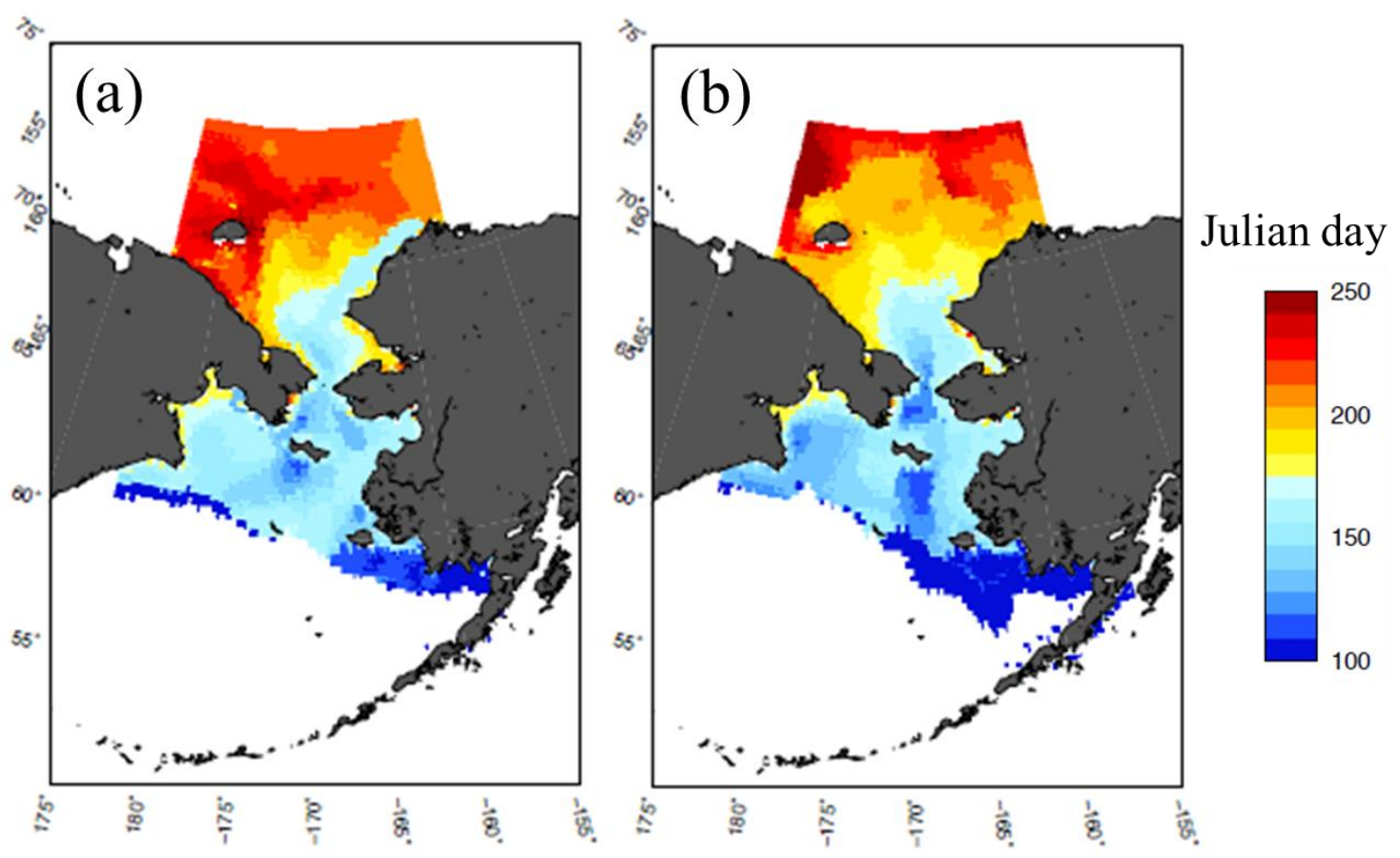

Figure S1. The timing of sea-ice retreat in 2012 (a) and 2013 (b). Different color shows Julian day. The timing of sea-ice retreat was defined by the first Julian day when sea-ice concentrations were below 10\%, following Fujiwara et al. (2016). Daily sea-ice concentrations were obtained by the Defense Meteorological Satellite Program (DMSP) special sensor microwave imager (SSM/I) with $25 \mathrm{~km}$ spatial resolution.

Fujiwara, A., Hirawake, T., Suzuki, K., Eisner, L., Imai, I., Nishino, S., Kikuchi, T., and Saitoh, S.-I.: Influence of timing of sea ice retreat on phytoplankton size during marginal ice zone bloom period on the Chukchi and Bering shelves, Biogeosciences, 13, 115-131, doi:10.5194/bg-13-115-2016, 2016. 


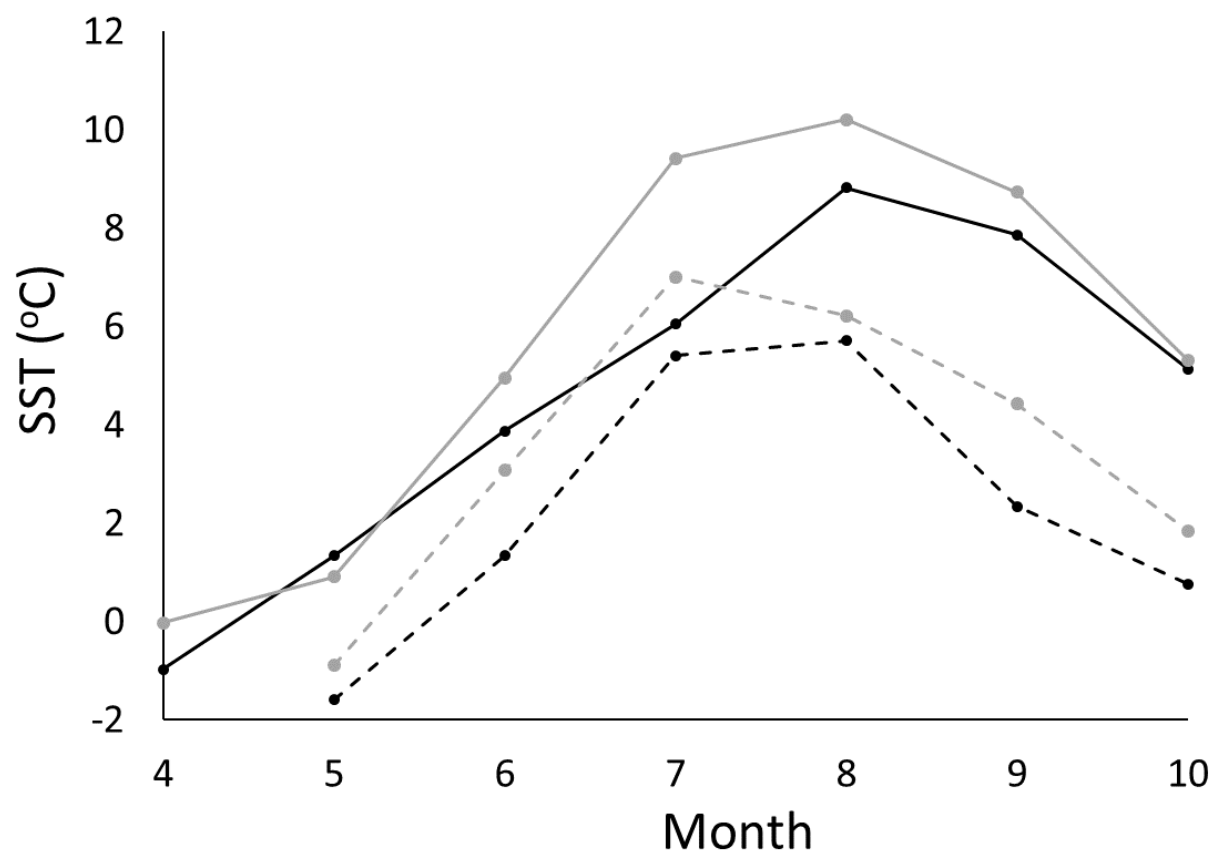

Figure S2. Seasonal changes in SST in the southeastern Bering Sea shelf $\left(56^{\circ} 40 \mathrm{~N}\right.$, $163^{\circ} 52 \mathrm{~W}$, solid line) and southern Chukchi Sea $\left(68^{\circ} 03 \mathrm{~N}, 168^{\circ} 50 \mathrm{~W}\right.$, broken line) during 2012 (black line) and 2013 (gray line). Monthly SST data were obtained from moderateresolution spectroradiometer/Aqua standard mapped images with a spatial resolution of approximately $9 \mathrm{~km}$ provided by Ocean Color website (http://oceancolor.gsfc.nasa.gov). 

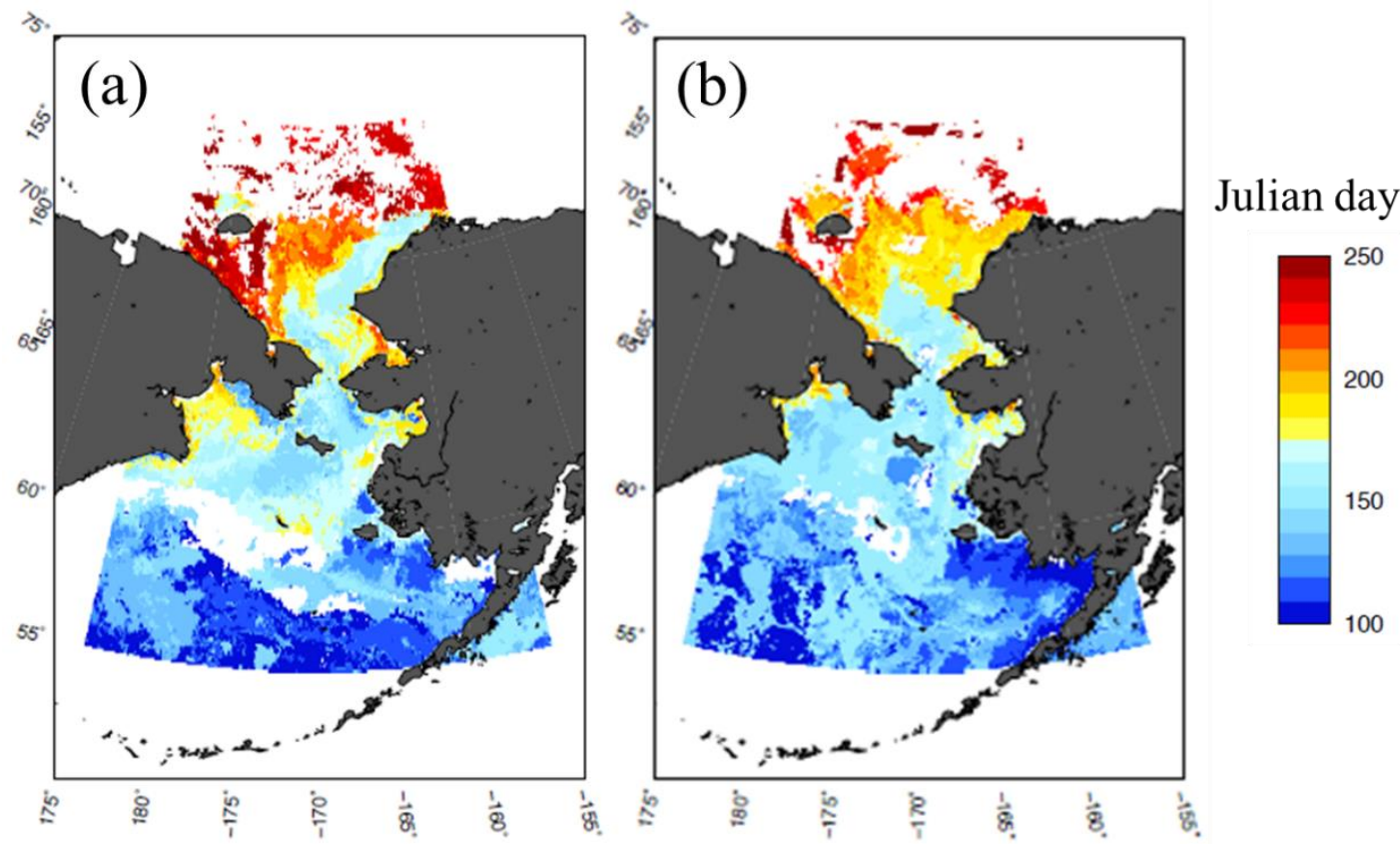

Figure S3. The timing of spring bloom indicated by Julian day when occurrence of Chl $a$ maximum within 20 days after sea-ice retreat in (a) 2012 and (b) 2013. Different color shows Julian day. Daily chlorophyll $a$ concentrations data were obtained from moderateresolution spectroradiometer/Aqua standard mapped images with a spatial resolution of approximately $9 \mathrm{~km}$ provided by Ocean Color website (http://oceancolor.gsfc.nasa.gov). Missing value (i.e., cloud cover) shows in white color. 